\title{
Determinants of Multi-Drug Resistant Tuberculosis Among Patients Attending Anti-Tuberculosis Treatment From Peripheral Districts, Southern Ethiopia, 2019: a Case Control Study
}

Lankamo Ena Digesa ( $\square$ lankamoena@gmail.com )

Arba Minch University https://orcid.org/0000-0003-2132-1666

Aklil Hailu Beyene

Addis Ababa University College of Health Sciences

Erdaw Tachbele Betre

Addis Ababa University College of Health Sciences

Research article

Keywords: MDR-TB, Determinants, Case control, Southern Ethiopia

Posted Date: August 6th, 2020

DOI: https://doi.org/10.21203/rs.3.rs-38359/v1

License: (c) (1) This work is licensed under a Creative Commons Attribution 4.0 International License.

Read Full License 


\section{Abstract}

Background: The emergence of multi-drug resistant tuberculosis (MDR-TB) is a challenge for global prevention and control of the disease. MDR-TB case management is difficult because it exposes to further economic and social costs that the patients face while seeking help and treatment. Ethiopia is one of the 30 MDR-TB burden countries. There is little research evidence of MDR-TB from the peripheral parts of the country.

Objective: The study was designed to identify determinants of MDR-TB among patients attending anti tuberculosis treatment from peripheral districts, Southern Nations, Nationalities and People Region, Ethiopia, 2019.

Methods: Hospital based case control study was conducted from March to April, 2019 in Southern Ethiopia. Cases were confirmed MDR-TB patients, while controls were those who declared cured or completed first line ant-tuberculosis treatment. The study participants were recruited by stratified random sampling. The data were entered into Epi data 4.4.3, cleaned and analyzed by SPSS 24 . Bivariate and multivariable analyses was used to identify determinants of MDR-TB. Determinants with P-value $<0.05$ were declared as having significant association with MDR-TB and adjusted odd ratio with $95 \% \mathrm{Cl}$ was used to measure degree of association.

Result: A total of 180 study participants were recruited (90 cases and 90 controls) and participated in this study. The median age for cases and controls was 29 and 30.5 years respectively. More than two third (78.89\%) of case participants were from rural and $49(54.44 \%)$ of the controls were from rural. Uneducated [AOR:5.18, 95\% Cl (1.69-15.80)], rural resident [AOR:2.60,95\% CI(1.14-6.88)], body mass index(BMI)<18.5kg/m²[AOR:3.11,95\% Cl(1.41-6.88], pulmonary tuberculosis[AOR:3.98,95\% Cl(1.11-14.22)], contact history with tuberculosis patient [AOR:3.99,95\% Cl (1.75-9.07)] and history of previous treatment[AOR:9.5,95\% Cl(4.08-22)] were found independent determinants of MDR-TB.

Conclusions and Recommendation: Uneducated, rural residence, body mass index $<18.5 \mathrm{~kg} / \mathrm{m}^{2}$, pulmonary tuberculosis, contact history with tuberculosis patient and history of previous treatment were associated with MDR-TB. A community level education to enhance public awareness about MDR-TB, nutritional counseling and support, strengthening contact tracing and directly observed treatment strategies with treatment adherence interventions were recommended.

\section{Background}

Tuberculosis (TB) is an infectious disease caused by Mycobacterium tuberculosis. Commonly, TB affects the lungs but it can affect other parts of the body $(1,2)$. Multidrug-resistant (MDR) refers to TB caused by M. tuberculosis that is resistant to at least Isoniazid (INH) and Rifampicin. (2-4).

According to World Health Organization(WHO) 2018 TB report(1), 160,684 MDR/RR-TB cases were detected and notified in 2017. Of those, a total of 139,114 cases (87\%) were enrolled for second-line 
treatment (1). WHO 2019 TB report revealed that a total of 186,772 cases of MDR/TB were reported in 2018 , of which, 156, $071(83.6 \%)$ cases were enrolled for second-line treatment(5). There was a gap between the number of cases notified and started treatment $(1,6)$.

The emergence of multidrug resistant tuberculosis (MDR-TB) is a challenge for the global prevention and control of the disease(7). The Global Plan to End TB estimated that the amount for diagnosis and treatment of multidrug-resistant TB (MDR-TB) increases from US\$2.0 billion in 2017 to US\$ 3.6 billion by 2020(8). MDR-TB case management is difficult because it exposes to further economic and social costs that the patients face while seeking help and treatment(9).

Immune-compromising conditions ( HIV, under nutrition, smoking, and drug and alcohol abuse), history of previous treatment, contact history, body mass index below $18.5 \mathrm{Kg} / \mathrm{m}^{2}$, diabetes mellitus, chronic obstructive pulmonary diseases, smear positivity, history of hospitalization, stigma, history of imprisonment and being refugee camp were the risk factors for MDR-TB(1, 10-14).

A systematic review and meta-analysis in Sub Saharan countries showed that drug resistant TB among previously treated TB patients was highest in East Africa (15).World health organization 2018 global tuberculosis report indicated that Ethiopia is one of the 30 TB-burden countries (1). The report estimated that the incidence of MDR/RR-TB in 2017 in Ethiopia was 5.2(ranging 3.9-6.6)/100000 populations(1). A systematic review and meta-analysis of multidrug-resistant tuberculosis in Ethiopia revealed that overall prevalence of MDR-TB was 7.24\%(12). The prevalence of MDR-TB was higher than the previous review in 2017(16).

Ethiopian national TB program has no capacity to perform drug susceptibility testing for all incident TB cases for early identification of drug resistant TB(8), therefore it is important to prioritize patients based on the risk factors. Ethiopian Federal Ministry of Health set a strategic objective" Improve Equitable Access to Quality Health Services" to achieve from 2016-2020 through health sector transformation plan. This strategic objective deals with minimizing disparities between groups and regions with different levels of underlying social advantage/disadvantage in the provision of health services that distinguished economically, socially, demographically and geographically $(2,17)$.

A systematic review and meta-analysis published in 2018(12) revealed that almost all studies conducted in Ethiopia focused in main urban centers. This implies that there is little research evidence from the peripheral districts of the country. Besides, to this, the determinants of MDR-TB have been not explored in the current study area. Therefore, this study was designed to identify the determinants of multidrug resistant tuberculosis from peripheral districts in Southern Ethiopia.

\section{Methods}

\section{Study design, period and area}


Hospital based unmatched case control study design was conducted in Southern Nation, Nationalities and Peoples Region (SNNPR) to determine risk factors associated with MDR-TB in comparison to drug susceptible TB (DS-TB) patients. The study was conducted from March to April, 2019.

A population projection figure of 2012 based on 2007 national population and housing census, the population of the region was estimated to be $17,359,008(18)$. Since 2014 , there were six public hospitals serving as MDR/TB Treatment Initiation Center (TIC) in the Region. We selected three of these TIC, Namely: Yirgalem General Hospital, Quuen Eleni Memorial Hospital and Butajira General Hospital as our study sites. All the three hospitals have Directly Observed Treatment (DOT) center and a separate MDR/TB treatment initiation centers to manage drug susceptible tuberculosis (DS-TB) and MDR-TB patents respectively. Diagnosis and treatment of both drug susceptible and MDR-TB performed according to the guidelines for clinical and programmatic management of TB, leprosy and TB/HIV in Ethiopia(19).

\section{Source population}

All confirmed MDR-TB patients from peripheral districts and Drug Susceptible TB patients at the end first line anti-TB treatment attending Yirgalem, Butajira and Queen Elen Memorial Hospitals.

\section{Study population}

All confirmed MDR-TB patients from peripheral districts and Drug Susceptible TB patients at the end first line anti-TB treatment during study period attending Yirgalem, Butajira and Queen Elen Memorial Hospitals.

\section{Eligibility criteria}

MDR-TB confirmed patients by culture and/or drug susceptibility testing, and patients taking treatment and drug-susceptible TB patients declared cured or treatment completed at the end of first line ant-TB treatment were included in the study. Age below 15 years old, patients from main urban centers and seriously ill patients were excluded.

\section{Sample size determination}

Sample size was determined by a double population proportion formula. Epi-Info version 7.2.2.6 was used to calculate the number of study participants. Contact with a known TB patient in previous study that was conducted in East Shoa in Oromia(11) was used for sample size determination based on the following assumptions: $95 \%$ confidence level at power of $80 \%$, with the ratio of $1: 1$ case to control, percent of control exposed 39.7 and percent of cases exposed 61.6. The final sample size was 180 (90 cases and 90 controls).

\section{Sampling technique}

Cases were selected by stratified random sampling technique by considering the hospitals as strata for in-patient (admitted) and on follows up. Controls were recruited by stratified random sampling technique 
from the patients completed first line anti-TB drugs.

\section{Sampling procedure}

A total of 135 MDR-TB patients were from peripheral districts and 105 patients were eligible to complete first line anti-TB treatment during the study period. A stratum was made based on the hospital the patients attending. A proportional allocation to the size was made by a lottery method.

\section{Independent and dependent variables}

The outcome variable was multidrug resistant tuberculosis status (cases or controls). The predictor variables were sociodemographic characters like age, sex, marital status, occupation, educational status, monthly income, alcohol consumption, tobacco smoking, Khat chewing, imprisonment, staying in a refugee camp, consumption of raw meat and milk, living with cattle or domestic animals, nutritional status, site of TB, smear status, contact history, the history of previous TB treatment, hospitalization for TB, disclosure of TB status, co-morbidity, and HIV sero-status.

\section{Data collection instrument}

Data were collected by using pre-tested and structured questionnaire. Data collection tool was adopted from previous studies $(10,11,13,20-23)$.

\section{Data quality assurance}

Pre-test was carried out in All Africa Leprosy and TB Rehabilitation, and Training Center (ALERT) hospital before 1 week of main study. The questionnaire prepared in English was translated to Amharic then retranslated to English for consistency. Training was provided to $6 \mathrm{~B}$.Sc nurse health professionals who collected data before the beginning of data collection. After completing the interview session, additional data were collected from the MDR-TB and drug susceptible TB registers. To maintain validity of data, regular supervision was made by the principal investigator. The principal investigator and trained supervisors checked the completeness of each questionnaire and data accuracy on daily basis.

\section{Data processing and analysis}

The data were entered into Epi data 4.4.3 then exported to SPSS 24 for cleaning and analysis. The variables were described by frequencies, percentages, presented in tables and graphs. Median for income and age was calculated. Bivariate analysis was done to select the variables for multivariable analysis. The data were analyzed by logistic regression model. Variables with $p$-value $<0.25$ in bivariate analysis were entered to multivariable logistic regression to control confounding. Determinants with $P<0.05$ was considered as having a significant association with MDR-TB and AOR with $95 \% \mathrm{Cl}$ was used to measure a degree of association.

\section{Ethical clearance}


Ethical clearance was obtained from School of Nursing and Midwifery, Addis Ababa University, Research Ethics committee. The purpose of the study was explained to each study participant before data collection. Only those who gave consent to participate in the study was included in the study. The study participant was coded anonymously and confidentiality of information was maintained.

\section{Results}

\section{Socio-demographic characteristics of study participants}

A total of 180 study participants were recruited (90 cases and 90 controls) and participated in this study. More male respondents were found in cases $55(61.1 \%)$ as compared to controls $48(53.3 \%)$. Forty three $(47.78 \%)$ of cases were in age group of $26-45$ and $51(56.67 \%)$ of controls in the same category of age. The median age for cases and controls was 29 and 30.5 years respectively. Thirty-nine $(43.33 \%)$ of cases had average family monthly income of 501-1000 Ethiopian birr (ETB) and 43(47.78\%) of the control had the same amount. The median income for cases was 700 ETB ranging from 150-4000 ETB, and for the controls was 700 ETB ranging from 200-5000 ETB. More than two third (78.89\%) of case participants were from rural and nearly half $49(54.44 \%)$ of the controls were from rural. One third $(33.33 \%)$ of the cases were uneducated as compared to controls 15(16.67\%9(Table 1). 
Table 1

Distribution of socio-demographic characteristics of case and control respondents, Southern Ethiopia, 2019

\begin{tabular}{|c|c|c|c|c|c|c|}
\hline Variables Category & & Case (\%) & $\begin{array}{l}\text { Control } \\
\text { (\%) }\end{array}$ & Total (\%) & $\begin{array}{l}\text { Crude } \\
\text { OR(95\% Cl) }\end{array}$ & $\begin{array}{l}\mathrm{P} \\
\text { value }\end{array}$ \\
\hline \multirow[t]{2}{*}{ Sex } & Male & $55(61.1)$ & $48(53.3)$ & 103(57.22) & $\begin{array}{l}1.375(760- \\
2.48)\end{array}$ & 0.292 \\
\hline & Female & $35(38.9)$ & $42(46.7)$ & $77(42.78)$ & 1.00 & \\
\hline \multirow[t]{3}{*}{ Age } & $15-25$ & $37(41.1)$ & $30(33.33)$ & 67(37.22) & $\begin{array}{l}1.233(0.45- \\
3.35)\end{array}$ & 0.681 \\
\hline & $26-45$ & $43(47.8)$ & $50(55.56)$ & $93(51.67)$ & $\begin{array}{l}0.860(0.32- \\
2.26)\end{array}$ & 0.760 \\
\hline & $>=46$ & 10(11.1) & $10(11.11)$ & $20(11.11)$ & 1. 00 & \\
\hline \multirow{2}{*}{$\begin{array}{l}\text { Marital } \\
\text { Status }\end{array}$} & $\begin{array}{l}\text { Never } \\
\text { married }\end{array}$ & $34(37.8)$ & $35(38.9)$ & 69(38.33) & 1. 00 & \\
\hline & Married & $56(62.2)$ & $55(61.1)$ & 111(61.67) & $\begin{array}{l}1.048(0.57- \\
1.91)\end{array}$ & 0.878 \\
\hline \multirow{4}{*}{$\begin{array}{l}\text { Educational } \\
\text { Level }\end{array}$} & Uneducated & $30(33.3)$ & 15(16.7) & $45(25)$ & $\begin{array}{l}3.44(1.47- \\
8.05)\end{array}$ & 0.004 \\
\hline & $\begin{array}{l}\text { Read and } \\
\text { write }\end{array}$ & 12(13.3) & 15(16.7) & $27(15)$ & $\begin{array}{l}1.38(.53- \\
3.56)\end{array}$ & 0.511 \\
\hline & Primary & $30(33.3)$ & $29(32.2)$ & $59(32.78)$ & $\begin{array}{l}1.782(.82- \\
3.86)\end{array}$ & 0.143 \\
\hline & $\begin{array}{l}\text { Secondary \& } \\
\text { above }\end{array}$ & 18(20.0) & $31(34.4)$ & 49 (27.22) & 100. & \\
\hline \multirow[t]{2}{*}{ Occupation } & Employed & $14(15.56)$ & $18(20)$ & $32(17.78)$ & 1.00 & \\
\hline & Unemployed & $76(84.44)$ & $72(80)$ & 148(82.18) & $\begin{array}{l}1.357(0.63- \\
2.93)\end{array}$ & 0.437 \\
\hline \multirow[t]{3}{*}{$\begin{array}{l}\text { Average monthly } \\
\text { family income }\end{array}$} & $\leq 500$ & $29(32.2)$ & $27(30.0)$ & $56(31.1)$ & $\begin{array}{l}0.976(0.44- \\
2.17)\end{array}$ & 0.953 \\
\hline & $501-1000$ & $39(43.3)$ & $43(47.8)$ & $82(45.56)$ & $\begin{array}{l}0.825(0.39- \\
1.74)\end{array}$ & 0.612 \\
\hline & $>1000$ & $22(24.4)$ & $20(22.2)$ & $42(23.33)$ & 1.00 & \\
\hline \multirow[t]{2}{*}{ Residence } & Rural & 71(78.9) & $49(54.4)$ & $120(66.67)$ & $\begin{array}{l}3.127(1.62- \\
6.01)\end{array}$ & 0.001 \\
\hline & Urban & $19(21.1)$ & $41(45.6)$ & 60(33.33) & 1.00 & \\
\hline
\end{tabular}




\begin{tabular}{|lllllll|}
\hline Variables Category & & Case (\%) & $\begin{array}{l}\text { Control } \\
(\%)\end{array}$ & Total (\%) & $\begin{array}{l}\text { Crude } \\
\text { OR(95\% Cl) }\end{array}$ & \begin{tabular}{l} 
P value \\
\hline $\begin{array}{l}\text { Separate room for } \\
\text { living and sleeping }\end{array}$
\end{tabular} \\
\cline { 2 - 7 } & Yes & $33(36.7)$ & $35(38.9)$ & $68(37.78)$ & 1.00 & \\
& No & $57(63.3)$ & $55(61.1)$ & $112(62.22)$ & $\begin{array}{l}0.91(0.50- \\
1.66)\end{array}$ & 0.759 \\
\hline Cl: Confidence Interval OR: Odd Ratio & & & & & \\
\hline
\end{tabular}

\section{Distribution of behavioral characteristics of study participants}

Thirty four (18.89\%) of the study participants were alcohol consumers contributing the same count from the cases and controls (Table 2). 
Table 2

Distribution of behavioral determinants of case and control respondents Southern Ethiopia, 2019

\begin{tabular}{|c|c|c|c|c|c|c|}
\hline Variables & Category & $\begin{array}{l}\text { Cases } \\
(\%)\end{array}$ & $\begin{array}{l}\text { Control } \\
\text { (\%) }\end{array}$ & Total (\%) & $\begin{array}{l}\text { Crude } \\
\text { OR(95\% Cl) }\end{array}$ & $\begin{array}{l}P \\
\text { value }\end{array}$ \\
\hline \multirow{2}{*}{$\begin{array}{l}\text { History of alcohol } \\
\text { consumption }\end{array}$} & Yes & 17(18.9) & 17(18.9) & $34(17.78)$ & $1.0(0.47-.109)$ & 1.00 \\
\hline & No & $73(81.1)$ & $73(81.1)$ & 146(82.22) & 1.00 & \\
\hline \multirow[t]{2}{*}{$\begin{array}{l}\text { History of smoking } \\
\text { cigarette }\end{array}$} & Yes & $9(10)$ & $1(1.1)$ & $10(5.56)$ & $\begin{array}{l}9.9(1.22- \\
79.70)\end{array}$ & 0.031 \\
\hline & No & $81(90)$ & 89(98.9) & 170(94.44) & 1.00 & \\
\hline \multirow[t]{2}{*}{$\begin{array}{l}\text { History of chewing } \\
\text { Khat }\end{array}$} & Yes & $13(14.4)$ & $12(13.3)$ & 25(13.89) & $\begin{array}{l}1.1(0.47- \\
2.55)\end{array}$ & 0.829 \\
\hline & No & $77(86.6)$ & $78(86.7)$ & $155(86.11)$ & 1.00 & \\
\hline \multirow{2}{*}{$\begin{array}{l}\text { Imprisonment } \\
\text { history for any } \\
\text { case }\end{array}$} & Yes & $5(5.6)$ & $3(3.3)$ & $8(4.44)$ & $\begin{array}{l}1.7(0.65- \\
4.34)\end{array}$ & 0.32 \\
\hline & No & $85(94.4)$ & 87(96.7) & 172(95.56) & 1.00 & \\
\hline \multirow{2}{*}{$\begin{array}{l}\text { History of being a } \\
\text { refugee camp }\end{array}$} & Yes & $5(5.55)$ & $8(8.89)$ & $13(7.22)$ & 1.00 & \\
\hline & No & $85(94.45)$ & $82(91.11)$ & 167(92.78) & $\begin{array}{l}0.63(0.82- \\
1.90)\end{array}$ & 0.39 \\
\hline \multirow{2}{*}{$\begin{array}{l}\text { History of } \\
\text { consuming a raw } \\
\text { milk }\end{array}$} & Not at all & $26(28.9)$ & 19(21.1) & $45(25)$ & 1.00 & \\
\hline & Sometimes & $64(71.11)$ & 71(78.89) & $135(75)$ & 1.00 & \\
\hline \multirow{2}{*}{$\begin{array}{l}\text { History of } \\
\text { consuming raw } \\
\text { meat }\end{array}$} & Not at all & $21(23.33)$ & 17(18.89) & $38(21.11)$ & $\begin{array}{l}0.66(0.33- \\
1.30)\end{array}$ & 0.23 \\
\hline & Sometimes & $69(76.67)$ & $73(81.11)$ & 142(78.89) & 1.00 & \\
\hline \multirow[t]{2}{*}{$\begin{array}{l}\text { Living with cattle/ } \\
\text { domestic animals }\end{array}$} & Yes & $39(43.3)$ & 48(53.3) & 87(48.33) & $\begin{array}{l}0.76(0.37- \\
1.57)\end{array}$ & 0.46 \\
\hline & No & $51(56.7)$ & $42(46.7)$ & $93(51.67)$ & $\begin{array}{l}1.49(0.83- \\
2.70)\end{array}$ & 0.18 \\
\hline
\end{tabular}

\section{Distribution of clinical characteristics of study participants}

More than half of the cases $55(61.1 \%)$ had BMI less than $18.5 \mathrm{~kg} / \mathrm{m}^{2}$ whereas nearly one third $32(35.6 \%)$ of the control had body mass index less than $18.5 \mathrm{~kg} / \mathrm{m}^{2}$. About $85(94.4 \%)$ of the cases were pulmonary TB. From the cases, 47(52.2\%) had contact history with known TB patients as compared to control only one fourth $23(25.6 \%)$ had a contact history. Only $4(2.22 \%)$ of participants were found HIV positive of those $3(75 \%)$ was control. Only $8(4.44 \%)$ of the participants were with co-morbidities (DM and COPD), contributing the equal number of cases and controls(Table 3). 
Table 3

Distribution of clinical characteristics of case and control respondents Southern Ethiopia, 2019

\begin{tabular}{|c|c|c|c|c|c|c|}
\hline Variables & Category & $\begin{array}{l}\text { Cases } \\
(\%)\end{array}$ & Control(\%) & Total(\% ) & $\begin{array}{l}\text { Crude } \\
\text { OR(95\% } \\
\text { Cl) }\end{array}$ & $\begin{array}{l}P \\
\text { value }\end{array}$ \\
\hline \multirow[t]{2}{*}{$\mathrm{BMI}\left(\mathrm{Kg} / \mathrm{m}^{2}\right)$} & $\begin{array}{l}<18.5 \\
\mathrm{Kg} / \mathrm{m}^{2}\end{array}$ & $55(61.1)$ & $32(35.6)$ & $87(48.33)$ & $\begin{array}{l}2.85(1.56- \\
5.2)\end{array}$ & 0.001 \\
\hline & $\begin{array}{l}\geq 18.5 \\
\mathrm{Kg} / \mathrm{m}^{2}\end{array}$ & $35(38.9)$ & $58(64.4$ & $103(51.67)$ & 1.00 & \\
\hline \multirow[t]{2}{*}{ Site of TB } & Pulmonary & $85(94.4)$ & $68(75.6)$ & 153(85) & $\begin{array}{l}5.5(1.98- \\
15.28)\end{array}$ & 0.001 \\
\hline & $\begin{array}{l}\text { Extra } \\
\text { pulmonary }\end{array}$ & $5(5.6)$ & $22(24.4)$ & $27(15)$ & 1.00 & \\
\hline \multirow[t]{2}{*}{ Sputum smear } & Positive & $53(62.4)$ & $42(61.8)$ & $95(62.09)$ & $\begin{array}{l}0.97(0.51- \\
1.88)\end{array}$ & 0.941 \\
\hline & Negative & $32(37.6)$ & $26(38.2)$ & $58(37.91)$ & 1.00 & \\
\hline \multirow[t]{2}{*}{$\begin{array}{l}\text { History of contact with } \\
\text { TB patients }\end{array}$} & Yes & $47(52.2)$ & $23(25.6)$ & $70(38.89)$ & $\begin{array}{l}3.18(1.70- \\
5.97)\end{array}$ & 0.00 \\
\hline & No & $43(47.8)$ & $67(74.4)$ & $110(61.11)$ & 1.00 & \\
\hline \multirow[t]{2}{*}{$\begin{array}{l}\text { History of previous } \\
\text { treatment of TB }\end{array}$} & Yes & $56(62.2)$ & 17(18.9) & $73(40.56)$ & $\begin{array}{l}7.07(3.59- \\
13.9)\end{array}$ & 0.00 \\
\hline & No & $34(37.8)$ & 73(81.1) & $107(59.44)$ & 1.00 & \\
\hline \multirow[t]{2}{*}{$\begin{array}{l}\text { If treated TB, } \\
\text { hospitalization for TB }\end{array}$} & Yes & $17(30.4)$ & $5(29.4)$ & $22(30.14)$ & $\begin{array}{l}1.04(0.32- \\
3.43)\end{array}$ & 0.941 \\
\hline & No & $39(69.6)$ & $12(70.6)$ & $51(69.86)$ & 1.00 & \\
\hline \multirow{2}{*}{$\begin{array}{l}\text { If treated TB, } \\
\text { disclosure of TB status } \\
\text { for the family/relatives }\end{array}$} & Yes & $34(60.7)$ & 11(64.3) & $45(61.64)$ & $\begin{array}{l}0.84(0.27- \\
2.6)\end{array}$ & 0.797 \\
\hline & No & $22(39.5)$ & $6(35.7)$ & $28(38.36)$ & 1.00 & \\
\hline
\end{tabular}

\section{Multivariable analysis}

The predictors which were $\mathrm{p}$-value $<0.25$ in bivariate analysis were entered into multivariable logistic regression for statistically adjustment. The predictors which were candidate for multivariate analysis were checked for multi-collinearity before statistically adjustment in multivariable logistic regression. All the predictors pass the test of multi-collinearity (Variance inflation factor (VIF) is between 1.022 and 1.093)). Cigarette smoking was not included in multivariable analysis because of small number of observations. A goodness of fit of the model was assessed from the output of the multivariable logistic regression. Overall goodness of fit was 0.462 by Hosmer-Lemeshow test. 
The odds of MDR-TB in previous treatment were 10 times higher than were not treated TB(Pvalue:0.000;95\% $\mathrm{Cl}(\mathrm{AOR}: 9.5(4.08-22)$ ). The odds of developing MDR-TB in rural respondents was three times than urban(P value-0.029;95\% Cl(AOR:2.6(1.11-6.11))(Table 4).

Table 4

Multivariable logistic regression of case and control respondents, Southern Ethiopia, 2019

\begin{tabular}{|c|c|c|c|c|c|c|}
\hline Variable & Category & Case(\%) & Control(\% & $\begin{array}{l}\text { Crude OR 95\% } \\
\text { Cl }\end{array}$ & AOR 95\% Cl & $\begin{array}{l}P \\
\text { value }\end{array}$ \\
\hline \multirow[t]{4}{*}{ Educational level } & Uneducated & $30(33.3)$ & $15(16.7)$ & $\begin{array}{l}3.44(1.47- \\
8.05)\end{array}$ & $\begin{array}{l}5.18(1.7- \\
15.80)\end{array}$ & 0.004 \\
\hline & Read and write & $12(13.3)$ & $15(16.7)$ & $1.38(.53-3.56)$ & $\begin{array}{l}2.03(0.56- \\
7.33)\end{array}$ & 0.278 \\
\hline & Primary & $30(33.3)$ & $29(32.2)$ & $1.78(.82-3.86)$ & $\begin{array}{l}1.88(0.66- \\
5.23)\end{array}$ & 0.234 \\
\hline & $\begin{array}{l}\text { Secondary\& } \\
\text { above }\end{array}$ & $18(20.0)$ & $31(34.4)$ & 1.00 & 1.00 & \\
\hline \multirow[t]{2}{*}{ Residence } & Rural & 71(78.9) & $49(54.4)$ & $3.13(1.62-6.0)$ & $\begin{array}{l}2.6(1.11- \\
6.11)\end{array}$ & 0.029 \\
\hline & Urban & 19(21.1) & $41(45.6)$ & 1.00 & 1.00 & \\
\hline \multirow[t]{2}{*}{$\begin{array}{l}\text { Living with cattle/domestic } \\
\text { animals }\end{array}$} & Yes & $39(43.3)$ & $48(53.3)$ & $\begin{array}{l}1.5(0.83- \\
2.69)\end{array}$ & $\begin{array}{l}0.55(.248- \\
1.21)\end{array}$ & 0.136 \\
\hline & No & $51(56.7)$ & $42(46.7)$ & 1.00 & 1.00 & \\
\hline \multirow[t]{2}{*}{ Consuming a raw milk } & Sometimes & $64(71.1)$ & $71(78.9)$ & $\begin{array}{l}0.66(0.33- \\
1.3)\end{array}$ & $\begin{array}{l}1.01(0.38- \\
2.67)\end{array}$ & 0.984 \\
\hline & Not all & $26(28.9)$ & 19(21.1) & 1.00 & 1.00 & \\
\hline \multirow[t]{2}{*}{ Nutritional status } & $\begin{array}{l}\mathrm{BMI}< \\
18.5 \mathrm{~kg} / \mathrm{m} 2\end{array}$ & $55(61.1)$ & $32(35.6)$ & $2.85(1.5-5.2)$ & $\begin{array}{l}3.11(1.41- \\
6.68)\end{array}$ & 0.005 \\
\hline & $\begin{array}{l}\mathrm{BMI} \geq \\
18.5 \mathrm{~kg} / \mathrm{m} 2\end{array}$ & $35(38.9)$ & 58(64.4 & 1.00 & 1.00 & \\
\hline \multirow[t]{2}{*}{ Site of TB } & Pulmonary TB & $85(94.4)$ & $68(75.6)$ & $\begin{array}{l}5.5(1.98- \\
15.28)\end{array}$ & $\begin{array}{l}3.98(1.1- \\
14.22)\end{array}$ & 0.033 \\
\hline & Extra pulmonary & $5(5.6)$ & $22(24.4)$ & 1.00 & 1.00 & \\
\hline \multirow[t]{2}{*}{ Contact history TB Patient } & Yes & $47(52.2)$ & $23(25.6)$ & $\begin{array}{l}3.18(1.70- \\
5.97)\end{array}$ & $\begin{array}{l}3.99(1.75- \\
9.1)\end{array}$ & 0.001 \\
\hline & No & $43(47.8)$ & $67(74.4)$ & 1.00 & 1.00 & \\
\hline \multirow[t]{2}{*}{ History previous treatment of $\mathrm{TB}$} & 3 Yes & $56(62.2)$ & 17(18.9) & $\begin{array}{l}\text { 7.07(3.6- } \\
13.9)\end{array}$ & $9.5(4.08-22)$ & 0.000 \\
\hline & No & $34(37.8)$ & $73(81.1)$ & 1.00 & 1.00 & \\
\hline
\end{tabular}

\section{Discussion}

This unmatched case control study that was conducted on 180 respondents (90 cases and controls) to identify determinants of MDR-TB from patients peripheral districts revealed that uneducated, rural residence, body mass index less than $18.5 \mathrm{~kg} / \mathrm{m}^{2}$, pulmonary TB, contact history and previous treatment were found independent predictors of MDR-TB. The study addressed a number of possible determinants of MDR-TB but only the mentioned were found independent predictors. This might be due to the small number of observations in different predictors related with the small sample size. Therefore, the predictors which were found independent will be discussed as follow.

This study indicated that the odds of developing MDR-TB were five times (AOR: 5.18) higher in uneducated than who had education level of secondary and above. The finding was in agreement with study in Bangladesh(24). In contrast, Addis Ababa(10) greater than secondary had a significant 
association with MDR-TB. However, the studies in East Shoa(11) and Jimma(13),being uneducated were not associated with occurrence of MDR-TB, in Serbia(25); a level of education did not affect development of MDR-TB. This may be due to this study recruited the participants from peripheral districts and majority of the respondents were rural dwellers that might have a poor access for education and health literacy.

The current study revealed that rural residents had three times (AOR: 2.6) higher risk of MDR-TB than urban. This was in line with the study that was conducted in East Shoa(11). However, MDR-TB was not associated with residence according to the studies that were conducted in Jimma(13), China(26) and Iran(27). This difference might be due to access of TB services nearby and low knowledge of TB for drug adherence, transportation problem, inadequate social support and fear of stigma to complete anti-TB drugs.

The odds of being body mass index less than $18.5 \mathrm{~kg} / \mathrm{m}^{2}$ were 3 times (AOR:3.11) higher in cases than controls. The finding was in line with other findings $(1,2,28)$. A poor nutritional status decreases a probability of treatment success (response), increases recurrence, decreases smear conversion rate, reduces hosts immunity by enhancing bacilli development and resistance, and a malnutrition is highly common in MDR-TB patients and one of the risk factors for development of $\operatorname{MDR}-\mathrm{TB}(2,3,8,29)$.

The respondents with pulmonary TB four times(AOR:3.98) more likely developed MDR-TB than extrapulmonary TB. The finding was in line with study in East shoa(11), Addis Ababa(30),South Korea(28). However, the study in Jimma(13), pulmonary TB had no association with MDR-TB. The possible explanation for this could be higher risk of recurrence of drug resistant dormant bacilli which suppressed by previous TB drug exposure when hosts immunity gets weakened. The patients with pulmonary TB have a higher bacterial load which may not respond to first line anti-TB drugs in a short time. This affects adherence of patients(31).

Having a contact history with TB patient had four times(AOR:3.99) higher odds of MDR-TB than noncontact. The similar finding from the studies in East Shoa(11), Amhara regional state(32), Addis Ababa(10), systematic review and meta-analysis in Ethiopia(12), Tanzania(33),Equatorial Guinea(34),Bangladesh(35),India(36),USA(4). This is supported by $(2,8)$ having a contact is high risk group to develop MDR-TB. A higher chance of acquiring a drug resistant strain by droplets and aerosol from individuals infected with multidrug resistant strain $(6,37)$. However, a contact history in Iran(27) had no association with MDR-TB. This could be due to a small number of cases in Iran that lacks adequate power to identify association with MDR-TB.

The current study showed that the odds of MDR-TB in previously treated respondents were ten times(AOR:9.5) higher than treatment naïve respondents. And previous treatment was a major predictor of MDR-TB in this study. Similar findings were found in a number of studies from different countries including the Ethiopia, East Shoa(11), Amhara regional state(32), Addis Ababa(10), Iran and neighboring countries(38),Iran(27),Nepal(39),China(26),Sub-Saharan countries review(9), retrospective study in Nigeria(40), Equatorial Guinea(34), Tanzania(33), USA(4). Systematic review and meta-analysis in 
Ethiopia(12) revealed previous treatment was a major determinant of MDR-TB, systematic review in Europe(41). This is supported by WHO report (42)-previously treated patients are at higher risk of drug resistance and had non adherence(22).The resistance in a history of previous treatment might be due to multiple exposures to first line anti-TB drugs and incorrect methods of taking the treatment regimen that facilitate mutation of bacteria and development of resistance(2). However, the study in Serbia (17): a history previous treatment had no association with MDR-TB. This difference might be due to difference in adherence level, small sample size in Serbia and difference in study setting.

\section{Conclusion}

The study revealed that uneducated, rural residence, body mass index less than $18.5 \mathrm{~kg} / \mathrm{m}^{2}$, pulmonary TB, contact history and previous treatment had statistically significant association with a development of MDR-TB. Therefore, social mobilization and community level education by health extension workers, religious leaders, and community leaders to enhance public awareness about MDR-TB and quality of life. Nutritional counseling on proper nutrition and support, intensifying contact tracing strategies and address all contacts through the patients, screening all family members in the community. Arranging a regular TB education session at each community and schools, identification of the patients most likely relapse and giving attention for the patients who have a history of previous treatment by patient centered care approach, good communication skills and support, assuring well-functioning directly observed treatment strategies with treatment adherence interventions.

This study identified the determinants of MDR-TB from the peripheral districts. Since the study hospitals were at which the majority of the MDR-TB cases are managed, the study identified the relevant regional determinants of MDR-TB. But this study could not identify other known predictors of MDR-TB because of small number of observations related with small sample size and recall bias might affect the finding because some of the information was based on the recall of the study participants. Since, a previous treatment was found the major determinant for MDR-TB in this study and previous studies, this needs a further study to identify the factors related to MDR-TB in previously TB treated patients. As the hospitalized patients are subject to bias, a community-based study should be conducted.

\section{List Of Abbreviations}

AOR: Adjusted Odd Ratio

BMl: Body Mass Index

DS-TB: Drug Susceptible Tuberculosis

ETB: Ethiopian Birr

HIV: Human immunodeficiency virus 
MDR-TB: Multi-Drug Resistant Tuberculosis

SNNPR: Southern Nation, Nationalities and Peoples Region

TB: Tuberculosis

\section{Declarations}

\section{Ethics approval and consent to participate}

Ethical clearance was obtained from School of Nursing and Midwifery, Addis Ababa University, Research Ethics committee with the protocol number of 022/19/SNM. The purpose of the study was explained to each study participant before data collection. A written informed consent was taken. For those who were age under 16 years, a written guardian or parent consent was obtained. Only those who gave consent to participate in the study was included in the study.

\section{Consent for publication}

Not applicable.

\section{Availability of data and materials}

The datasets used and analyzed are available from the corresponding author on reasonable request.

\section{Competing interest}

The authors have no conflict of interest to declare for the study.

\section{Funding}

Arba Minch University in collaboration with Ethiopian Federal Ministry of Education

\section{Authors contribution}

LE wrote the proposal, participated in data collection, analyzed the data and prepared the manuscript.ET commented and approved the proposal, participated in data analysis and subsequent revision of draft of the paper and writing the draft of manuscript. AH commented and approved the proposal, participated in data analysis and subsequent revision of draft of the paper. All authors read and approved the final paper.

\section{Acknowledgement}

The authors acknowledge Addis Ababa University College of health sciences, School of Nursing and Midwifery, Arba Minch University College of Medicine and Health Sciences, regional health bureau, study participants and data collectors for their support and coordination for the success of this study. 


\section{References}

1. World Health organization. Global tuberculosis report. 2018.

2. Federal Ministry of Health. National guidelines for TB, DR-TB and Leprosy in Ethiopia. 2017.

3. Ethiopian Food Medicine Health Administration and Control Authory. Standard treatment guidelines for general hospitals 2014.

4. Brown J, Dooley D, Backer H. Drug-Resistant Tuberculosis. A Survival Guide for Clinicians third edition. 2016.

5. World Health organization. Global tuberculosis report. 2019.

6. World Health organization. Global tuberculosis report.2017.

7. World Health organization. Global tuberculosis report.2016.

8. Federal Ministry of Health. National Programmatic management of Drug resistant TB in Ethiopia. 2017.

9. World Health organization. Companion handbook to the WHO guidelines for the programmatic management of drug-resistant tuberculosis. 2014.

10. Assefa D, Seyoum B, Oljira L. Determinants of multidrug-resistant tuberculosis in Addis Ababa. Ethiopia Infection drug resistance. 2017;10:209.

11. Desissa F, Workineh T, Beyene T. Risk factors for the occurrence of multidrug-resistant tuberculosis among patients undergoing multidrug-resistant tuberculosis treatment in East Shoa, Ethiopia. BMC Public Health. 2018;18(1):422.

12. Girum T, Muktar E, Lentiro K, Wondiye $H$, Shewangizaw M. Epidemiology of multidrug-resistant tuberculosis (MDR-TB) in Ethiopia: a systematic review and meta-analysis of the prevalence, determinants and treatment outcome. Tropical Diseases, Travel Medicine and Vaccines. 2018;4(1):5.

13. Gobena D, Ameya G, Haile K, Abreha G, Worku Y, Debela T. Predictor of multidrug resistant tuberculosis in southwestern part of Ethiopia: a case control study. Ann Clin Microbiol Antimicrob. 2018;17(1):30.

14. World Health organization. Companion handbook to the WHO guidelines for the programmatic management of drug-resistant tuberculosis. 2014.

15. Lukoye D, Ssengooba W, Musisi K, Kasule GW, Cobelens FG, Joloba M, et al. Variation and risk factors of drug resistant tuberculosis in sub-Saharan Africa: a systematic review and meta-analysis. BMC Public Health. 2015;15(1):291.

16. Eshetie S, Gizachew M, Dagnew M, Kumera G, Woldie H, Ambaw F, et al. Multidrug resistant tuberculosis in Ethiopian settings and its association with previous history of anti-tuberculosis treatment: a systematic review and meta-analysis. BMC Infect Dis. 2017;17(1):219.

17. Federal Ministry of Health. Health sector transformation plan(HSTP). 2015.

18. Central Statistical Agency. Population size by sex, region, zone and wereda of Ethiopia.2012. 
19. Federal Ministry of Health. Guidelines for clinical and programmatic management of TB, leprosy and TB/HIV in Ethiopia. Addis Ababa: Ethiopian Ministry of Health; 2012.

20. Habteyes Hailu T, Azar T, Davoud SHOJAEIZADEHGG. Tuberculosis treatment non-adherence and lost to follow up among TB patients with or without HIV in developing countries: a systematic review. Iranian journal of public health. 2015;44(1):1.

21. Shitaye J, Tsegaye W, Pavlik I. Bovine tuberculosis infection in animal and human populations in Ethiopia: a review. VETERINARNI MEDICINA-PRAHA-. 2007;52(8):317.

22. Tesfahuneygn G, Medhin G, Legesse M. Adherence to Anti-tuberculosis treatment and treatment outcomes among tuberculosis patients in Alamata District, northeast Ethiopia. BMC Res Notes. 2015;8(1):503.

23. Tibebu M, Mekonnen W, Awoke T, Gebre-Selassie S, Yamuah L. A high prevalence of tuberculosis among dairy farm workers in Addis Ababa and its surroundings. Journal of Mycobacterial Diseases. 2014:4:139.

24. Rifat M, Milton AH, Hall J, Oldmeadow C, Islam MA, Husain A, et al. Development of multidrug resistant tuberculosis in Bangladesh: a case-control study on risk factors. PloS one. 2014;9(8):e105214.

25. Stosic M, Vukovic D, Babic D, Antonijevic G, Foley KL, Vujcic I, et al. Risk factors for multidrugresistant tuberculosis among tuberculosis patients in Serbia: a case-control study. BMC Public Health. 2018;18(1):1114.

26. Zhang C, Wang Y, Shi G, Han W, Zhao H, Zhang H, et al. Determinants of multidrug-resistant tuberculosis in Henan province in China: a case control study. BMC Public Health. 2015;16(1):42.

27. Afshari M, Aarabi M, Parsaee M, Nezammahalleh A, Moosazadeh M. Determinant factors of drug resistant tuberculosis in Iran, a case control study. Clinical Epidemiology and Global Health. 2018.

28. Park H-O, Kim S-H, Moon S-H, Byun J-H, Kim J-W, Lee C-E, et al. Association between body mass index and sputum culture conversion among South Korean patients with multidrug resistant tuberculosis in a tuberculosis referral hospital. Infection chemotherapy. 2016;48(4):317-23.

29. World Health Organization. Consolidated guidelines on drug-resistant tuberculosis treatment. Geneva: World Health Organization; 2019.

30. Dessalegn M, Daniel E, Behailu S, Wagnew M, Nyagero J. Predictors of multidrug resistant tuberculosis among adult patients at Saint Peter Hospital Addis Ababa, Ethiopia. The Pan African Medical Journal. 2016;25(Suppl 2).

31. Muñoz-Sellart M, Cuevas L, Tumato M, Merid Y, Yassin M. Factors associated with poor tuberculosis treatment outcome in the Southern Region of Ethiopia. Int J Tuberc Lung Dis. 2010;14(8):973-9.

32. Mulu W, Mekkonnen D, Yimer M, Admassu A, Abera B. Risk factors for multidrug resistant tuberculosis patients in Amhara National Regional State. Afr Health Sci. 2015;15(2):368-77.

33. Lema NA, Mbelele PM, Majigo M, Abade A, Matee MI. Risk factors associated with multidrug resistant tuberculosis among patients referred to Kibong'oto Infectious Disease Hospital in northern Tanzania. Tanzania Journal of Health Research. 2016;18(4). 
34. Izco S, Eyene J, Pérez-Lago L, Herranz M, Biyé L, Noeske J, et al. Equatorial Guinea, a multidrugresistant tuberculosis hotspot in Central Africa. Eur Respir J. 2017;49(1):1600952.

35. Flora M, Amin M, Karim M, Afroz S, Islam S, Alam A, et al. Risk factors of multi-drug-resistant tuberculosis in Bangladeshi population: a case control study. Bangladesh Med Res Counc Bull. 2013;39(1):34-41.

36. Raazi J, Prakash S, Parveen K, Shaikh S. Risk factors of multi-drug resistant tuberculosis in urban Allahabad, India. International Journal Of Community Medicine Public Health. 2017;4(7):2383-8.

37. Federal Ministry of Health. Guideline for clinical and programmatic management of TB, TB/HIV and Leprosy in Ethiopia. 2016.

38. Jimma W, Ghazisaeedi M, Shahmoradi L, Abdurahman AA, Kalhori SRN, Nasehi M, et al. Prevalence of and risk factors for multidrug-resistant tuberculosis in Iran and its neighboring countries: systematic review and meta-analysis. Rev Soc Bras Med Trop. 2017;50(3):287-95.

39. Marahatta S, Kaewkungwal J, Ramasoota P, Singhasivanon P. Risk factors of multidrug resistant tuberculosis in central Nepal: a pilot study. Kathmandu University Medical Journal. 2010;8(4):392-7.

40. Daniel O, Osman E. Prevalence and risk factors associated with drug resistant TB in South West, Nigeria. Asian Pacific journal of tropical medicine. 2011;4(2):148-51.

41. Faustini A, Hall AJ, Perucci CA. Risk factors for multidrug resistant tuberculosis in Europe: a systematic review. Thorax. 2006;61(2):158-63.

42. World Health Organization. Initiative ST. Treatment of tuberculosis: guidelines: World Health Organization; 2010.

\section{Supplementary Files}

This is a list of supplementary files associated with this preprint. Click to download.

- MDRTBDatasetssavthenew.cleaned.sav 